\title{
Plasma 8-Isoprostane Concentrations and Adipogenic and Adipokine Gene Expression Patterns in Subcutaneous and Mesenteric Adipose Tissues of Fattening Wagyu Cattle
}

\author{
Tomoya YAMADA ${ }^{1) *}$, Mikito HIGUCHI ${ }^{1)}$ and Naoto NAKANISHI ${ }^{1)}$ \\ ${ }^{1)}$ Institute of Livestock and Grassland Science, National Agriculture and Food Research Organization, Nasushiobara, Tochigi 329-2793, \\ Japan
}

(Received 8 February 2013/Accepted 16 March 2013/Published online in J-STAGE 29 March 2013)

\begin{abstract}
We hypothesized that fattening Wagyu cattle fed conventional low-vitamin fattening diets are exposed to oxidative stress. In this experiment, we studied the plasma concentrations of 8-isoprostane and the fat depot-specific effects of the diet-induced adipogenic (C/ $\mathrm{EBP} \beta, \mathrm{C} / \mathrm{EBP} \delta, \mathrm{C} / \mathrm{EBP} \alpha$ and PPAR $\gamma 2$ ) and adipokine (VEGF, FGF-2, leptin and adiponectin) gene expressions in fattening Wagyu steers. Animals were fed a high-vitamin ( $\alpha$-tocopherol and $\beta$-carotene) diet (HV) or a control diet (CT) during the fattening period (from 10 to 30 months of age). The plasma concentrations of 8-isoprostane, a marker of oxidative stress, were significantly lower in the HV group than in the CT group. In mesenteric adipose tissue, the expressions of the adipogenic and adipokine genes in the HV group were significantly lower than those in the CT group. In contrast, there were no differences in the expression of the adipogenic and adipokine genes in subcutaneous adipose tissue between groups. These results suggest that higher intake of dietary $\alpha$-tocopherol and $\beta$-carotene affects the expression patterns of adipogenic and adipokine genes in a fat depot-specific manner with the reduction of plasma 8-isoprostane concentrations.
\end{abstract}

KEY WORDS: adipocyte, adipokine, cattle.

doi: 10.1292/jvms.13-0071; J. Vet. Med. Sci. 75(8): 1021-1027, 2013

Adipose tissue growth (adipogenesis) is dependent on cellular events concerning both the increase in the number of adipocytes (hyperplasia) and the enlargement of adipocyte size (hypertrophy). Adipogenic transcription factors, the CCAAT/enhancer-binding protein (C/EBP) family $(\mathrm{C} / \mathrm{EBP} \beta, \mathrm{C} / \mathrm{EBP} \delta$ and $\mathrm{C} / \mathrm{EBP} \alpha)$ and the peroxisome proliferator-activated receptor $\gamma 2$ (PPAR $\gamma 2$ ), play essential roles during adipogenesis [7, 27, 34]. Previous studies have also indicated that adipogenesis is tightly associated with angiogenesis [23, 28]. The adipocyte itself secretes many angiogenic adipokines, such as the vascular endothelial growth factor (VEGF) and the fibroblast growth factor-2 (FGF-2) $[11,20]$. In addition, leptin and adiponectin, major adipokines secreted from adipocytes, are potent inducers of angiogenesis [5, 25, 31, 32].

Obesity is characterized by increased oxidative stress with chronic inflammation in adipose tissues. Obese subjects have higher levels of oxidative stress biomarkers, such as 8-isoprostane, than their leaner counterparts. 8-isoprostane is an eicosanoid produced by the random oxidation of lipids by oxygen radicals, and its plasma levels accurately reflect the oxidative stress status in obese patients [2, 35, 36]. On the other hand, previous reports have indicated that dietary supplementation with $\alpha$-tocopherol, the most potent antioxidant component among vitamin $\mathrm{E}$, reduced oxidative stress

\footnotetext{
*Correspondence to: Yamada, T., Institute of Livestock and Grassland Science, National Agriculture and Food Research Organization, 768 Senbonmatsu, Nasushiobara, Tochigi 329-2793, Japan. e-mail: toyamada@affrc.go.jp

C2013 The Japanese Society of Veterinary Science
}

with the reduction of plasma 8-isoprostane concentrations in obese patients $[17,37,38]$. In addition, a lower dietary intake of $\alpha$-tocopherol and $\beta$-carotene in humans increases the oxidative stress status [13]. Previous studies have also indicated that plasma levels of 8 -isoprostane are significantly correlated with visceral fat area rather than subcutaneous one $[2,35]$. Ito et al. $[15]$ reported that the $\mathrm{C} / \mathrm{EBP} \beta$ up-regulates the expression of inflammatory mediator adipokines, such as MCP-1 and IL-6. Leptin induces oxidative stress by leading to an enhanced intracellular accumulation of reactive oxygen species [3], and the serum leptin concentration has a positive relationship with oxidative stress levels [21]. These results suggest that a higher dietary intake of $\alpha$-tocopherol and $\beta$-carotene reduces oxidative stress via down-regulation of adipogenic and adipokine genes mainly in mesenteric adipose tissue. However, the effects of the dietary $\alpha$-tocopherol and $\beta$-carotene levels on the expression of the adipogenic and adipokine genes in adipose tissues, including humans and rodents, are still unclear. In addition, although feedlot cattle are thought to be in a state of obesity, little is known about the status of oxidative stress in fattening ruminants. In this experiment, we studied the effects of the dietary $\alpha$-tocopherol and $\beta$-carotene levels on the concentrations of plasma 8-isoprostane and the expression of adipogenic $(\mathrm{C} / \mathrm{EBP} \beta, \mathrm{C} / \mathrm{EBP} \delta, \mathrm{C} / \mathrm{EBP} \alpha$ and $\mathrm{PPAR} \gamma 2)$ and adipokine (VEGF, FGF-2, leptin and adiponectin) genes in the adipose tissue of fattening Wagyu steers.

\section{MATERIALS AND METHODS}

Animals: The experimental design has been described in detail by Yamada et al. [40]. In brief, eight Wagyu steers 
aged 10 months were allotted by body weight to two groups. (1) The control group (CT, n=4) farmed under conventional feeding system: fed concentrate $(88 \%$ total digestible nutrients (TDN), $0.1 \mathrm{mg} / \mathrm{kg} \beta$-carotene and $2 \mathrm{mg} / \mathrm{kg} \alpha$-tocopherol) and orchard grass hay $(56 \% \mathrm{TDN}, 0.5 \mathrm{mg} / \mathrm{kg} \beta$-carotene and $3 \mathrm{mg} / \mathrm{kg} \alpha$-tocopherol) during the experimental periods (fed from 10 to 30 months). The control group was fed diet consisting of about $10 \%$ roughage and $90 \%$ concentrate (on a TDN basis). (2) The high-vitamin diet group ( $H V, n=4)$ fed $\alpha$-tocopherol and $\beta$-carotene rich total mixed rations (TMR) consisting of $72 \% \mathrm{TDN}, 16 \mathrm{mg} / \mathrm{kg} \beta$-carotene and $60 \mathrm{mg} /$ $\mathrm{kg} \alpha$-tocopherol (fed from 10 to 20 months), and 77\% TDN, $7 \mathrm{mg} / \mathrm{kg} \beta$-carotene and $22 \mathrm{mg} / \mathrm{kg} \alpha$-tocopherol (fed from 21 to 30 months). Dietary vitamin concentrations were measured as described previously [26]. Feeds were individually provided in each group. The steers were pair-fed in order to eliminate the influence of the total TDN intake between groups. At 30 months of age, the steers were slaughtered by captive bolt stunning and exsanguinations after $48 \mathrm{hr}$ fasting, and the subcutaneous and mesenteric adipose tissues were sampled. The subcutaneous adipose tissue was collected near the 3 rd and 4 th lumbar vertebrae. The mesenteric adipose tissue was sampled from the area surrounding the colon. All adipose tissue samples were collected immediately after slaughter, and samples were stored at $-80^{\circ} \mathrm{C}$ in the RNA-later reagent (Ambion, CA, U.S.A.) until RNA extraction. After slaughter, the left side of the carcass was chilled for $72 \mathrm{hr}$ at $4^{\circ} \mathrm{C}$ and physically separated into muscle, bone and fat to measure the tissue weight. All animals received humane care as outlined in the Guide for the Care and Use of Experimental Animals (Institute of Livestock and Grassland Science).

Plasma 8-isoprostane analysis: Three days before slaughter, blood samples were collected from the jugular vein. Plasma was separated by centrifugation and stored at $-80^{\circ} \mathrm{C}$ until analysis. The plasma levels of free 8-isoprostane were measured using an ELISA kit (Cayman Chemical, Ann Arbor, MI, U.S.A.) according to the manufacturer's protocol.

RNA isolation and real-time PCR: Adipogenic and adipokine gene expressions were analyzed by real-time PCR as described previously $[39,41]$. In brief, total RNA was extracted from adipose tissue using the RiboPure kit (Ambion) according to the manufacturer's instructions. The first-strand cDNA was reverse-transcribed from $0.5 \mu \mathrm{g}$ total RNA using the ReverTra Ace qPCR RT kit (Toyobo, Osaka, Japan) according to the manufacturer's protocol. Real-time PCR was performed with a Mini Opticon (Bio-Rad, Munich, Germany) using THUNDERBIRD SYBR qPCR Mix (Toyobo) according to the manufacturer's instructions. The primer sequences were as follows: C/EBP $\beta, 5^{\prime}$-ACA GCG ACG AGT ACA AGA TCC-3' (forward) and 5'-GAC AGT TGC TCC ACC TTC TTC T-3' (reverse); C/EBP $\delta, 5^{\prime}$-ATC GAC TTC AGC GCC TAC AT-3' (forward) and 5'-GCT TTG TGG TTG CTG TTG AA-3' (reverse); C/EBP $\alpha, 5$ '-CCG TGG ACA AGA ACA AGC AAC-3' (forward) and 5'-TGG TCA GCT CCA GCA CCT TC-3' (reverse); PPAR $\gamma 2$, 5'-GTG AAG TTC AAC GCA CTG GA-3' (forward) and 5'-ATG TCC TCA ATG GGC TTC AC-3' (reverse); VEGF, 5'-GAA
CTT TCT GCT CTC TTG GG-3' (forward) and 5'-CTG GCT TTG GTG AGG TTT GA-3' (reverse); FGF-2, 5'-ACC GGT CAA GGAAAT ACT CCA G-3' (forward) and 5'-CAG GTC CTG TTT TGG GTC CA-3' (reverse); leptin, 5'-GGA GAA GGT CCC GGA GGT T-3' (forward) and 5'- GGA CCA GAC ATT GGC GAT CT-3' (reverse); adiponectin, 5'- CAC AAT GGG GTC TAT GCA GAT-3' (forward) and 5'-GTT ATG GTAG AGA AGG AAG CCT GT-3'(reverse); ribosomal protein large P0 (RPLP0), 5'-CAA CCC TGA AGT GCT TGA CAT-3' (forward) and 5'-AGG CAG ATG GAT CAG CCA-3' (reverse). The reaction conditions were designed as follows: initial denaturation at $95^{\circ} \mathrm{C}$ for $60 \mathrm{sec}$ followed by 40 cycles at $95^{\circ} \mathrm{C}$ for $15 \mathrm{sec}, 55^{\circ} \mathrm{C}$ for $15 \mathrm{sec}$ and $70^{\circ} \mathrm{C}$ for $30 \mathrm{sec}$. SYBR green fluorescence was detected at the end of each cycle to monitor the amount of the realtime PCR product formed during that cycle. The specificity of the PCR products was determined by melting curve analysis at the end of each run. The standard curve of each product followed the calculation of respective gene expressions. The expression levels of adipogenic and adipokine mRNA were normalized by RPLP0 as an internal control [39, 41]. The expression in the HV group in each adipose tissue was set to one, and the expression in the control group was expressed as the value relative to that in the HV group.

Adipocyte cellularity: Adipocyte cellularity was measured as described previously [41]. In brief, the samples of adipose tissue were rinsed in $0.154 \mathrm{M} \mathrm{NaCl}$ and then fixed with 50 $\mathrm{mM}$ collidine- $\mathrm{HCl}$ buffer $(\mathrm{pH} 7.4)$ containing $2 \%$ osmium tetroxide. After fixation, the samples were rinsed in 0.154 $\mathrm{M} \mathrm{NaCl}$ for $24 \mathrm{hr}$ at room temperature. Fixed adipose tissue samples were then placed into $8 \mathrm{M}$ urea in $0.154 \mathrm{M} \mathrm{NaCl}$ for $48 \mathrm{hr}$ at room temperature. Fixed and urea-isolated adipocytes were separated into $0.01 \%$ Triton X-100 in a $0.154 \mathrm{M}$ $\mathrm{NaCl}$ buffer ( $\mathrm{pH} 10)$. The adipocyte diameter was measured using WinRoof software (Mitani Corporation, Fukui, Japan). Over 300 adipocytes for each sample were measured.

Statistical analysis: All results are presented as the means $\pm \mathrm{SD}$. The differences in mean values between the groups were analyzed by Student's $t$-test using the StatView Version 5 program (SAS Institute, Inc., Cary, NC, U.S.A.).

\section{RESULTS}

Carcass data: The growth performance and feed intake of Wagyu steers have been described in earlier reports [40]. Briefly, there were no significant differences in the final body weight, daily gain and total TDN intakes between groups. Table 1 shows the carcass composition and regional variation of adipose tissue in Wagyu steers between groups. There were no significant differences in the weights of carcass composition (bone and lean) and distribution of adipose tissues (subcutaneous and mesenteric) between groups.

Plasma 8-isoprostane concentrations: The plasma 8-isoprostane concentrations are shown in Fig. 1. The plasma 8-isoprostane concentrations in the HV group were significantly lower than those in the CT group.

Adipogenic and adipokine gene expression and adipocyte cellularity: In subcutaneous adipose tissue, there were no 
Table 1. Carcass data of Wagyu steers

\begin{tabular}{lcr}
\hline Carcass composition & CT & \multicolumn{1}{c}{ HV } \\
\hline Bone $(\mathrm{kg})^{\text {a) }}$ & $26.8 \pm 0.4$ & $28.4 \pm 1.7$ \\
Lean $(\mathrm{kg})^{\text {a) }}$ & $117.0 \pm 10.8$ & $114.2 \pm 6.9$ \\
${\text { Subcutaneous }(\mathrm{kg})^{\text {a) }}}^{\text {Mesenteric }}(\mathrm{kg})$ & $28.0 \pm 8.1$ & $27.7 \pm 9.7$ \\
\hline
\end{tabular}

Values are expressed as Mean $\pm \mathrm{SD}$. Control diet group (CT, $\mathrm{n}=4)$, High-vitamin diet group $(\mathrm{HV}, \mathrm{n}=4)$. a) The data from the left side of the carcass.

differences in the adipogenic $(\mathrm{C} / \mathrm{EBP} \beta, \mathrm{C} / \mathrm{EBP} \delta, \mathrm{C} / \mathrm{EBP} \alpha$ and PPAR $\gamma$ 2) and adipokine (VEGF, FGF-2, leptin and adiponectin) gene expression levels between groups (Fig. 2A and 2B). In the photomicrographs of osmium-fixed subcutaneous adipocytes, larger sizes of cells were more abundant in the HV group than in the CT group (Fig. 2C and 2D). Compared to the CT group, the subcutaneous adipocyte size distribution in the HV group shifted toward larger diameters (Fig. 2E). The mean diameter of subcutaneous adipocytes in the HV group was significantly larger than that in the CT group (Fig. 2F).

In mesenteric adipose tissue, the gene expression of $\mathrm{C} /$ $\mathrm{EBP} \beta, \mathrm{C} / \mathrm{EBP} \delta$ and $\mathrm{C} / \mathrm{EBP} \alpha$ in the HV group was significantly lower than that in the CT group (Fig. 3A). The gene expression of adipokine gene (VEGF, FGF-2, leptin and adiponectin) in the HV group was significantly lower than that in the CT group (Fig. 3B). The mean diameter of mesenteric adipocytes in the HV group was significantly larger than that in the CT group (Fig. 3C-F).

\section{DISCUSSION}

The present results showed that plasma 8-isoprostane concentrations in the CT group were significantly higher than those in the HV group. Obese patients exhibit significantly higher risk of oxidative stress with an increase of plasma 8 -isoprostane levels $[2,35,36]$. In addition, a lower dietary intake of fruit and vegetables in humans increases the oxidative stress status by the reduction of $\alpha$-tocopherol and $\beta$-carotene ingestion [13]. Feedlot cattle are generally fed a lower percentage of roughage and a higher percentage of concentrate diets. Wagyu cattle are characterized by the ability to accumulate a high amount of adipose tissue [18] and are conventionally fed a low- $\beta$-carotene diet to improve the marbling scores [24]. Irie et al. [14] reported that the concentration of $\alpha$-tocopherol and $\beta$-carotene in conventional fattening diet is low, and Wagyu cattle farmed under conventional feeding system have a low carcass-tissue- $\alpha$-tocopherol level. Our previous report also showed that the plasma and tissue concentration of $\alpha$-tocopherol in the CT group was significantly lower than that in the HV group [40]. These results suggest that beef cattle that have a higher level of body fat, especially Wagyu receiving low-vitamin conventional fattening diets, are exposed to oxidative stress. These results also indicated that higher intake of dietary $\alpha$-tocopherol and $\beta$-carotene reduced oxidative stress both in obese humans and fattening ruminants.

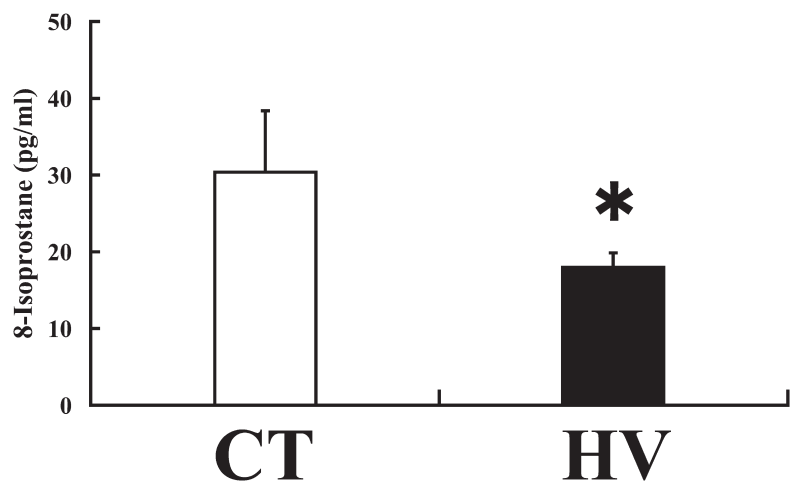

Fig. 1. Plasma levels of 8-isoprostane in Wagyu fattening steers aged 30 months fed a control (CT) or a high-vitamin (HV) diet during the entire fattening period (from 10 to 30 months of age). The data represent the means $\pm \mathrm{SD}$. ${ }^{*} P<0.05$.

In this study, we showed that there were no significant differences in the weights of subcutaneous and mesenteric adipose tissues between groups. We also showed that, although there were no differences in the expression of the adipogenic and adipokine genes in subcutaneous adipose tissues between groups, the expressions of the adipogenic (C/ $\mathrm{EBP} \beta, \mathrm{C} / \mathrm{EBP} \delta$ and $\mathrm{C} / \mathrm{EBP} \alpha$ ) and adipokine (VEGF, FGF-2, leptin and adiponectin) genes in the mesenteric adipose tissue of the HV group were significantly lower than those in the CT group. The present results indicated that the dietary conditions affect the expression pattern of adipogenic and adipokine genes in a fat depot-specific manner without affecting adipose tissue weight.

Interestingly, in the present study, we found that the mean diameter of subcutaneous and mesenteric adipocytes in the HV group was significantly larger than that in the CT group. The frequency of adipocyte death is positively correlated with increased adipocyte size in obese mice and humans [6]. Alkhouri et al. [1] also showed that the diet-induced hypertrophic adipocytes of obese mice are under apoptotic pressure, and the rates of adipocyte death increase dramatically in obesity. In contrast, previous studies showed that the administration of $\alpha$-tocopherol prevents oxidant-induced apoptosis $[19,30,33]$. This raises the possibility that the observed increase in subcutaneous and mesenteric adipocyte sizes in the HV group could be affected by the suppression of apoptosis in hypertrophic adipocytes, which is a result of the reduction of oxidative stress by the intake of a high$\alpha$-tocopherol diet. Further studies are needed to clarify the effects of dietary conditions on the adipocyte cellularity in bovine adipogenesis.

Obesity is associated with a low-grade chronic inflammation of adipose tissues. Ito et al. [15] reported that the C/ EBP family up-regulates the expression of inflammatory mediator adipokines. The expression of leptin and adiponectin after stimulation by nutrients markedly increased in visceral adipose tissue compared with subcutaneous adipose tissue [8]. Kawada et al. [16] reported that the administration of a higher level of $\alpha$-tocopherol inhibits the differentiation of 


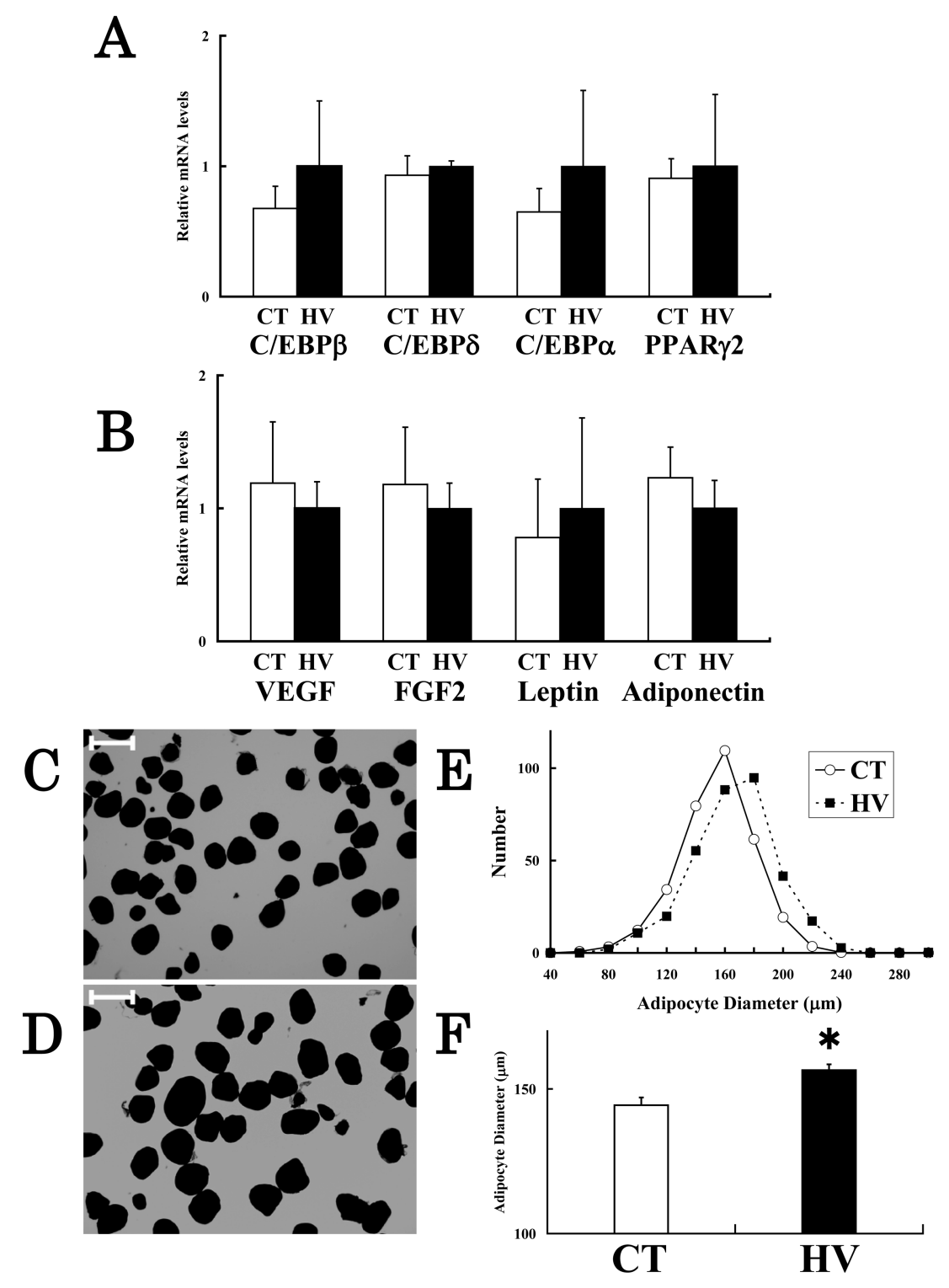

Fig. 2. Adipogenic (C/EBP $\beta, \mathrm{C} / \mathrm{EBP} \delta, \mathrm{C} / \mathrm{EBP} \alpha$ and PPAR $\gamma 2)$ and adipokine (VEGF, FGF-2, leptin and adiponectin) gene expression and adipocyte cellularity in subcutaneous adipose tissue of Wagyu steers fed a control (CT) or a high-vitamin (HV) diet during the entire fattening period (from 10 to 30 months of age). A), B) Expression of A) adipogenic and B) angiogenic mRNA in subcutaneous adipose tissue. RPLP0 mRNA was used as an internal control. C), D) Osmium tetroxide-fixed adipocytes from subcutaneous adipose tissue in the C) control (CT) and D) high-vitamin (HV) group. The white scale bar indicates $300 \mu \mathrm{m}$. E) Distributions of the diameters of subcutaneous adipocytes. F) Mean adipocyte diameter of subcutaneous adipose tissue. The data represent the means \pm SD. $* P<0.05$.

3T3-L1 preadipocytes. In addition, dietary supplementation of $\alpha$-tocopherol significantly decreased the VEGF expression in mice [22]. The present study indicated that a higher intake of dietary $\alpha$-tocopherol reduces the expressions of the adipogenic $(\mathrm{C} / \mathrm{EBP} \beta, \mathrm{C} / \mathrm{EBP} \delta$ and $\mathrm{C} / \mathrm{EBP} \alpha)$ and adipokine (VEGF, FGF-2, leptin and adiponectin) genes in mesenteric adipose tissue with the reduction of plasma 8-isoprostane levels. Studies on the regional differences of adipose tis- sue showed that visceral adipose tissue, when compared to subcutaneous adipose tissue, plays a key role in elevating the risk of metabolic syndrome with increased inflammation in humans $[10,12,29]$. The expression of inflammatory mediator adipokines in visceral adipose tissue is higher than that in subcutaneous adipose tissue $[4,9]$. In addition, oxidative stress is strongly associated with visceral adiposity rather than subcutaneous one $[2,35]$. These results suggest 

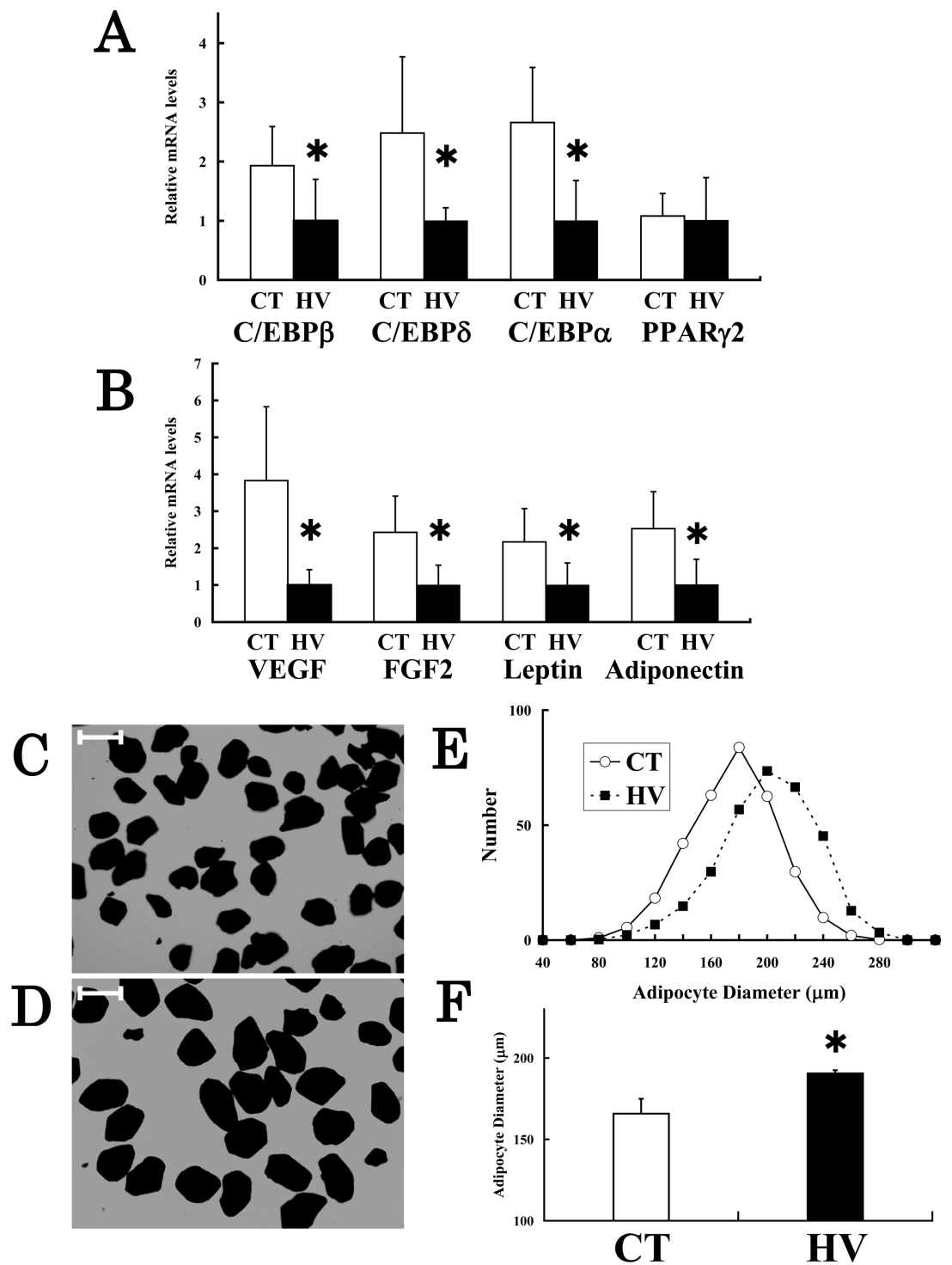

Fig. 3. Adipogenic (C/EBP $\beta, \mathrm{C} / \mathrm{EBP} \delta, \mathrm{C} / \mathrm{EBP} \alpha$ and PPAR $\gamma 2)$ and adipokine (VEGF, FGF-2, leptin and adiponectin) gene expression and adipocyte cellularity in mesenteric adipose tissue of Wagyu steers fed a control (CT) or a high-vitamin (HV) diet. A), B) Expression of A) adipogenic and B) angiogenic mRNA in mesenteric adipose tissue. RPLP0 mRNA was used as an internal control. ${ }^{*} P<0.05$. C), D) Osmium tetroxide-fixed adipocytes from mesenteric adipose tissue in the C) control (CT) and D) high-vitamin (HV) group. The white scale bar indicates $300 \mu \mathrm{m}$. E) Distributions of the diameters of mesenteric adipocytes. F) Mean adipocyte diameter of mesenteric adipose tissue. The data represent the means $\pm \mathrm{SD}$. $* P<0.05$.

that a reduction of oxidative stress by the dietary intake of $\alpha$-tocopherol and $\beta$-carotene might be affected by the downregulation of adipogenic and adipokine genes in mesenteric adipose tissue.

In conclusion, we showed that a higher intake of dietary $\alpha$-tocopherol and $\beta$-carotene reduces the plasma concentrations of 8-isoprostane and down-regulates the expressions of the adipogenic and adipokine genes in mesenteric adipose tissue. In contrast, there were no differences in the expression of the adipogenic and adipokine genes in subcutaneous adipose tissue between groups. These results suggest that a higher intake of dietary $\alpha$-tocopherol and $\beta$-carotene affects the expression patterns of adipogenic and adipokine genes in a fat depot-specific manner with the reduction of plasma 8 -isoprostane concentrations.

ACKNOWLEDGMENT. This work was supported in part by a Grant-in-Aid for Scientific Research from the Japan Society for the Promotion of Science (No.24580399). 


\section{REFERENCES}

1. Alkhouri, N., Gornicka, A., Berk, M. P., Thapaliya, S., Dixon, L. J., Kashyap, S., Schauer, P. R. and Feldstein, A. E. 2010. Adipocyte apoptosis, a link between obesity, insulin resistance, and hepatic steatosis. J. Biol. Chem. 285: 3428-3438. [Medline] [CrossRef]

2. Araki, S., Dobashi, K., Yamamoto, Y., Asayama, K. and Kusuhara, K. 2010. Increased plasma isoprostane is associated with visceral fat, high molecular weight adiponectin, and metabolic complications in obese children. Eur. J. Pediatr. 169: 965-970. [Medline] [CrossRef]

3. Bouloumie, A., Marumo, T., Lafontan, M. and Busse, R. 1999. Leptin induces oxidative stress in human endothelial cells. FASEB J. 13: 1231-1238. [Medline]

4. Bruun, J. M., Lihn, A. S., Pedersen, S. B. and Richelsen, B. 2005. Monocyte chemoattractant protein-1 release is higher in visceral than subcutaneous human adipose tissue (AT): Implication of macrophages resident in the AT. J. Clin. Endocrinol. Metab. 90: 2282-2289. [Medline] [CrossRef]

5. Cao, R., Brakenhielm, E., Wahlestedt, C., Thyberg, J. and Cao, Y. 2001. Leptin induces vascular permeability and synergistically stimulates angiogenesis with FGF-2 and VEGF. Proc. Natl. Acad. Sci. U.S.A. 98: 6390-6395. [Medline] [CrossRef]

6. Cinti, S., Mitchell, G., Barbatelli, G., Murano, I., Ceresi, E., Faloia, E., Wang, S., Fortier, M., Greenberg, A. S. and Obin, M. S. 2005. Adipocyte death defines macrophage localization and function in adipose tissue of obese mice and humans. J. Lipid Res. 46: 2347-2355. [Medline] [CrossRef]

7. Darlington, G. J., Rose, S. E. and MacDougald, O. A. 1998. The role of C/EBP genes in adipocyte differentiation. J. Biol. Chem. 273: 30057-30060. [Medline] [CrossRef]

8. Einstein, F. H., Atzmon, G., Yang, X., Ma, X. H., Rincon, M., Rudin, E., Muzumdar, R. and Barzilai, N. 2005. Differential responses of visceral and subcutaneous fat depots to nutrients. Diabetes 54: 672-678. [Medline] [CrossRef]

9. Fain, J. N., Madan, A. K., Hiler, M. L., Cheema, P. and Bahouth, S. W. 2004. Comparison of the release of adipokines by adipose tissue, adipose tissue matrix, and adipocytes from visceral and subcutaneous abdominal adipose tissues of obese humans. Endocrinology 145: 2273-2282. [Medline] [CrossRef]

10. Fernandez-Veledo, S., Vila-Bedmar, R., Nieto-Vazquez, I. and Lorenzo, M. 2009. c-Jun N-terminal kinase $1 / 2$ activation by tumor necrosis factor-a induces insulin resistance in human visceral but not subcutaneous adipocytes: reversal by liver $\mathrm{X}$ receptor agonists. J. Clin. Endocrinol. Metab. 94: 3583-3593. [Medline] [CrossRef]

11. Gabrielsson, B. G., Johansson, J. M., Jennische, E., Jernas, M., Itoh, Y., Peltonen, M., Olbers, T., Lönn, L., Lönroth, H., Sjöström, L., Carlsson, B., Carlsson, L. and Lönn, M. 2002. Depot-specific expression of fibroblast growth factors in human adipose tissue. Obes. Res. 10: 608-616. [Medline] [CrossRef]

12. Gauthier, M. S., O’Brien, E. L., Bigornia, S., Mott, M., Cacicedo, J. M., Xu, X. J., Gokce, N., Apovian, C. and Ruderman, N. 2011. Decreased AMP-activated protein kinase activity is associated with increased inflammation in visceral adipose tissue and with whole-body insulin resistance in morbidy obese humans. Biochem. Biophys. Res. Commun. 404: 382-387. [Medline] [CrossRef]

13. Helmersson, J., Arnlov, J., Larsson, A. and Basu, S. 2009. Low dietary intake of $\beta$-carotene, $\alpha$-tocopherol and ascorbic acid is associated with increased inflammatory and oxidative stress status in a Swedish cohort. Br. J. Nutr. 101: 1775-1782. [Medline]
[CrossRef]

14. Irie, M., Inno, Y., Ishizuka, Y., Nishioka, T. and Morita, T. 2006. Vitamins $\mathrm{A}$ and $\mathrm{E}$ in carcass fat from Japanese black and $\mathrm{F} 1$ cross cattle. Asian-Aus. J. Anim. Sci. 19: 1266-1270.

15. Ito, Y., Daitoku, H. and Fukamizu, A. 2009. Foxol increase pro-inflammatory gene expression by inducing C/EBP $\beta$ in TNF$\alpha$-treated adipocytes. Biochem. Biophys. Res. Commun. 378: 290-295. [Medline] [CrossRef]

16. Kawada, T., Aoki, N., Kamei, Y., Maeshige, K., Nishiu, S. and Sugimoto, E. 1990. Comparative investigation of vitamins and their analogues on terminal differentiation, from preadipocytes to adipocytes, of 3T3-L1 cells. Comp. Biochem. Physiol. A Comp. Physiol. 96: 323-326. [Medline] [CrossRef]

17. Laight, D. W., Desai, K. M., Gopaul, N. K., Anggard, E. E. and Carrier, M. J. 1999. F2-isoprostane evidence of oxidant stress in the insulin resistant, obese Zucker rat: effects of vitamin E. Eur. J. Pharmacol. 377: 89-92. [Medline] [CrossRef]

18. Matsuzaki, M., Takizawa, S. and Ogawa, M. 1997. Plasma insulin metabolite concentrations and carcass characteristics of Japanese Black, Japanese Brown, and Holstein steers. J. Anim. Sci. 75: 3287-3293. [Medline]

19. Mazlan, M., Sue Mian, T., Mat Top, G. and Zurinah Wan Ngah, W. 2006. Comparative effects of $\alpha$-tocopherol and $\gamma$-tocotrienol against hydrogen peroxide induced apoptosis on primarycultured astrocytes. J. Neurol. Sci. 243: 5-12. [Medline] [CrossRef]

20. Miyazawa-Hoshimoto, S., Takahashi, K., Bujo, H., Hashimoto, N., Yagui, K. and Saito, Y. 2005. Roles of degree of fat deposition and its localization on VEGF expression in adipocytes. $\mathrm{Am}$. J. Physiol. Endocrinol. Metab. 288: E1128-E1136. [Medline]

21. Nakanishi, S., Yamane, K., Kamei, N., Nojima, H., Okubo, M. and Kohno, N. 2005. A protective effect of adiponectin against oxidative stress in Japanese Americans: the association between adiponectin or leptin and urinary isoprostane. Metabolism 54: 194-199. [Medline] [CrossRef]

22. Nespereira, B., Perez-Ilzarbe, M., Fernandez, P., Fuentes, A. M., Paramo, J. A. and Rodriguez, J. A. 2003. Vitamin C and E downregulate vascular VEGF and VEGFR-2 expression in apolipoprotein-E deficient mice. Atherosclerosis 171: 67-73. [Medline] [CrossRef]

23. Nishimura, S., Manabe, I., Nagasaki, M., Hosoya, Y., Yamashita, H., Fujita, H., Ohsugi, M., Tobe, K., Kadowaki, T., Nagai, R. and Sugiura, S. 2007. Adipogenesis in obesity requires close interplay between differentiating adipocytes, stromal cells, and blood vessels. Diabetes 56: 1517-1526. [Medline] [CrossRef]

24. Oka, A., Maruo, Y., Miki, T., Yamasaki, T. and Saito, T. 1998. Influence of vitamin A on the quality of beef from the Tajima strain of Japanese black cattle. Meat Sci. 48: 159-167. [Medline] [CrossRef]

25. Ouchi, N., Kobayashi, H., Kihara, S., Kumada, M., Sato, K., Inoue, T., Funahashi, T. and Walsh, K. 2004. Adiponectin stimulates angiogenesis by promoting cross-talk between AMPactivated protein kinase and Akt signaling in endothelial cells. $J$. Biol. Chem. 279: 1304-1309. [Medline] [CrossRef]

26. Roeber, D. L., Belk, K. E., Tatum, J. D., Wilson, J. W. and Smith, G. C. 2001. Effects of three levels of $\alpha$-tocopheryl acetate supplementation to feedlot cattle on performance of beef cuts during retail display. J. Anim. Sci. 79: 1814-1820. [Medline]

27. Rosen, E. D. and Spiegelman, B. M. 2000. Molecular regulation of adipogenesis. Annu. Rev. Cell Dev. Biol. 16: 145-171. [Medline] [CrossRef]

28. Rupnick, M. A., Panigrahy, D., Zhang, C. Y., Dallabrida, S. M., Lowell, B. B., Langer, R. and Folkman, M. J. 2002. Adipose 
tissue mass can be regulated through the vasculature. Proc. Natl. Acad. Sci. U.S.A. 99: 10730-10735. [Medline] [CrossRef]

29. Sam, S., Haffner, S., Davidson, M. Sr., D’Agostino, R. B., Feinstein, S., Kondos, G., Perez, A. and Mazzone, T. 2009. Relation of abdominal fat depots to systemic markers of inflammation in type 2 diadetes. Diabetes Care 32: 932-937. [Medline] [CrossRef]

30. Serbecic, N. and Beutelspacher, S. C. 2005. Vitamins inhibit oxidant-induced apoptosis of corneal endothelial cells. Jpn. J. Ophthalmol. 49: 355-362. [Medline] [CrossRef]

31. Shibata, R., Ouchi, N., Kihara, S., Saito, K., Funahashi, T. and Walsh, K. 2004. Adiponectin stimulates angiogenesis in response to tissue ischemia through stimulation of AMP-activated protein kinase signaling. J. Biol. Chem. 279: 28670-28674. [Medline] [CrossRef]

32. Sierra-Honigmann, M. R., Nath, A. K., Murakami, C., GarciaCardena, G., Papapetropoulos, A., Sessa, W. C., Madge, L. A., Schechner, J. S., Schwabb, M. B., Polverini, P. J. and FloresRiveros, J. R. 1998. Biological action of leptin as an angiogenic factor. Science 281: 1683-1686. [Medline] [CrossRef]

33. Takahashi, H., Kosaka, N. and Nakagawa, S. 1998. $\alpha$-tocopherol protects PC12 cells from hyperoxia-induced apoptosis. J. Neurosci. Res. 52: 184-191. [Medline] [CrossRef]

34. Tontonoz, P., Hu, E., Graves, R. A., Budavari, A. I. and Spiegelman, B. M. 1994. mPPAR $\gamma 2$ : tissue-specific regulator of an adipocyte enhancer. Genes Dev. 8: 1224-1234. [Medline] [CrossRef]

35. Urakawa, H., Katsumi, A., Sumida, Y., Gabazza, E. C., Murashima, S., Morioka, K., Maruyama, N., Kitagawa, N., Tanaka, T., Hori, Y., Nakatani, K., Yano, Y. and Adachi, Y. 2003. Oxidative stress is associated with adiposity and insulin resistance in men. J. Clin. Endocrinol. Metab. 88: 4673-4676. [Medline] [CrossRef]

36. Vincent, H. K., Innes, K. E. and Vincent, K. R. 2007. Oxidative stress and potential interventions to reduce oxidative stress in overweight and obesity. Diabetes Obes. Metab. 9: 813-839. [Medline] [CrossRef]

37. Ward, N. C., Wu, J. H. Y., Clarke, M. W., Puddey, I. B., Burke, V., Croft, K. D. and Hodgson, J. M. 2007. The effect of vitamin E on blood pressure in individuals with type 2 diabetes: a randomized, double-blind, placebo-controlled trial. J. Hypertens. 25: 227-234. [Medline] [CrossRef]

38. Wu, J. H. Y., Ward, N. C., Indrawan, A. P., Almeida, C. A., Hodgson, J. M., Proudfoot, J. M., Puddey, I. B. and Croft, K. D. 2007. Effects of $\alpha$-tocopherol and mixed tocopherol supplementation on markers of oxidative stress and inflammation in type 2 diabetes. Clin. Chem. 53: 511-519. [Medline] [CrossRef]

39. Yamada, T. and Nakanishi, N. 2012. Effects of roughage/concentrate ratio on the expression of angiogenic growth factors in adipose tissue of fattening Wagyu steers. Meat Sci. 90: 807-813. [Medline]

40. Yamada, T., Higuchi, M. and Nakanishi, N. 2012. Effects of fermented TMR containing whole crop rice silage on carcass traits and lipid stability of meat in Japanese black steers. Bull. Beef Cattle Sci. 92: 4-9.

41. Yamada, T., Kawakami, S. and Nakanishi, N. 2010. Fat depotspecific differences in angiogenic growth factor gene expression and its relation to adipocyte size in cattle. J. Vet. Med. Sci. 72: 991-997. [Medline] [CrossRef] 